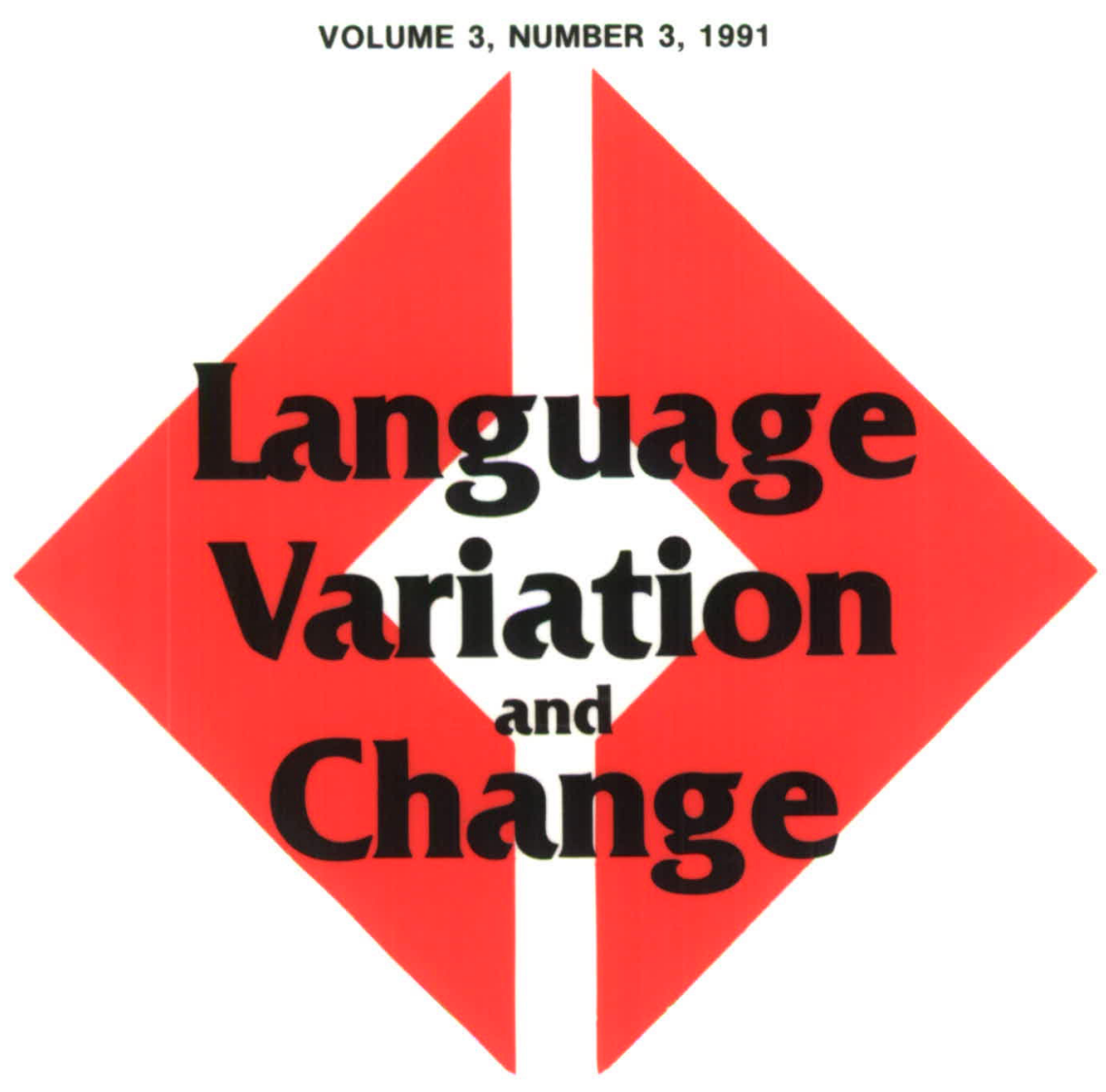

\title{
Editors
}

\section{David Sankoff}

Université de Montréal

\section{William Labov}

University of Pennsylvania

\author{
Anthony Kroch
}

University of Pennsylvania

\section{CAMBRIDGE UNIVERSITY PRESS}




\title{
\& Language Variation and Change
}

\author{
EDITORS
}

\section{DAVID SANKOFF}

Université de Montréal

\author{
WILLIAM LABOV \\ University of Pennsylvania
}

\author{
ANTHONY KROCH \\ University of Pennsylvania
}

\section{EDITORIAL BOARD}

Guy Bailey, Texas $A \& M$

Henrietta Cedergren, Université du Québec

à Montréal

Gregory Guy, Stanford University

Frank Jansen, University of Leiden

Anthony Naro, Federal University of Rio de Janeiro

Shana Poplack, University of Ottawa
Gillian Sankoff, University of Pennsylvania

Deborah Schiffrin, Georgetown University

Fernando Tarallo, State University

of Campinas

Gunnel Tottie, University of Zurich

Peter Trudgill, University of Essex

Walt Wolfram, Center for Applied Linguistics, Washington, $D C$

Editorial Assistant: Jane Warren

\section{EDITORIAL POLICY}

Language Variation and Change is dedicated to the description and understanding of variability and change at the levels of the speaker/hearer and the speech community. The journal will concentrate on the details of structure and process that have traditionally constituted the discipline of linguistics, as reflected in actual speech production and processing (or writing) and as systematically analyzed using quantitative methods. The interaction between language and society falls within the focus of the journal insofar as it is manifested in linguistic structure.

\section{PUBLISHING, SUBSCRIPTION, AND ADVERTISING OFFICES}

(For U.S.A. and Canada) Cambridge University Press, 40 West 20th Street, New York, NY 10011, U.S.A. (For U.K. and elsewhere) Cam- bridge University Press, The Edinburgh Building, Shaftesbury Road, Cambridge CB2 2RU, England.

\section{SUBSCRIPTION INFORMATION}

Language Variation and Change (ISSN 0954-3945) is published triannually. For Volume 3 (1991), the subscription rates are: Institutional, US $\$ \$ 2.00$ (U.S.A. and Canada), UK $£ 34.00$ (U.K. and elsewhere); Individual, US $\$ 27.00$ (U.S.A. and
Canada), UK $£ 17.00$ (U.K. and elsewhere). Single issues: US $\$ 18.00$ (U.S.A. and Canada), UK $£ 12.00$ (U.K. and elsewhere). Notify the nearest Cambridge office 6 weeks in advance of an address change.

\section{(C) 1992 Cambridge University Press}

All rights reserved. No part of this publication may be reproduced, in any form or by any means - photocopying, electronic, or otherwise - without written permission from Cambridge University Press.

Photocopying information for users in the U.S.A. The Item-Fee Code for this publication $(0954-3945 / 92 \$ 5.00+.00)$ indicates that copying for internal or personal use beyond that permitted by Sec. 107 or 108 of the U.S. Copyright Law is authorized for users duly registered with the Copyright Clearance Center (CCC) Transaction Reporting Service, provided that the appropriate remittance of $\$ 5.00$ per article is paid directly to: CCC, 27 Congress Street, Salem, MA 01970. Specific written permission must be obtained from Cambridge University Press for all other copying. 